\title{
Effect of CAR and NPL on ROA: Empirical Study in Indonesia Banks
}

\author{
Jannati TANGNGISALU' ${ }^{1}$, Rusdiah HASANUDDIN² Yusriadi HALA $^{3}$, \\ Nurlina NURLINA ${ }^{4}$, Syahruni SYAHRUL ${ }^{5}$
}

Received: March 13, 2020 Revised: March 28, 2020 Accepted: May 07, 2020

\begin{abstract}
This study seeks to analyze the effect of Non-Performing Loans and Capital Adequacy Ratio on Return on Assets on ten conventional banks listed on the Indonesia Stock Exchange (BEI-IDX). This study uses secondary panel data for 2015-2019 in the form of CAR and NPL values from ten conventional banks listed on the BEI-IDX during the 2020 observation period. The research approach is quantitative descriptive with data analysis methods, namely, linear regression. The testing phase of this study includes: transform value, F-test, T-test and hypothesis test with significancy level sig $<0.05$. The results of this study reveal that Non-Performing Loans had a significant negative effect $(\mathrm{t}=$ $-2,637)(0.011<0.0)$ on Return on Assets, while Capital Adequacy Ratio has no significant effect on ROA $(0.760>0.05)$. R2 value is 0.128 or $12.8 \%$. It has a significant effect on variables, calling efforts by banks, governments, and authorities monetary of related institutions to maintain the stability of finance. The reduction of Non-Performing Loan impacts on assets and capital adequacy ratio, besides, the normal NPL will control the stability of finance. If a balance is created either in the form of values or amounts of the variables, the reduction in Non-Performing Loans will be controlled.
\end{abstract}

Keywords: Non-Performing Loan, Capital Adequacy Ratio, Return on Assets, Indonesia

JEL Classification Code: G38, G32, G17, G18

\section{Introduction}

This study aims to make several scientific contributions to the scope of financial management through theoretical implications and suggest managerial implications, especially for the banking industry in Indonesia. This is a new article

${ }^{1}$ First Author and Corresponding Author. Associate Professor, Department of Management, STIEM Bongaya, Makassar, Indonesia [Postal Address: Jalan. Let. Jend. Mappaoddang No.28, Bongaya, Kec. Tamalate, Kota Makassar, Sulawesi Selatan 90131, Indonesia] Email: tanggisalu.bongaya@gmail.com

${ }^{2}$ Associate Professor, Department of Management, STIE YPUP, Makassar, Indonesia. Email: rusdiah.ypup@gmail.com

${ }^{3}$ Assistant Professor, Department of Accounting, STIEM Bongaya, Makassar, Indonesia

${ }^{4}$ Associate Professor, Department of Management, STIMI YAPMI, Makassar, Indonesia

${ }^{5}$ Finance and Tax Consultant, Karya Asrindah.cv, Makassar, Indonesia

(c) Copyright: The Author(s)

This is an Open Access article distributed under the terms of the Creative Commons Attribution Non-Commercial License (http://Creativecommons.org/licenses/by-nc/4.0/) Attribution Non-Commercial License (http://Creativecommons.org/licenses/by-nc/4.0/)
which permits unrestricted noncommercial use, distribution, and reproduction in any medium, provided the original work is properly cited. that examines ten large conventional banks in Indonesia, which are listed on the Indonesia Stock Exchange, by looking from the perspective of the analysis of the ratio of financial risk and its impact on the profitability of conventional banks. Therefore, this study involves testing empirically with the regression analysis model the influence of the non-Performing loan (NPL) variable and the Capital Adequacy Ratio (CAR) to the Return on Assets (ROA) of ten conventional banks listed on the Indonesia Stock Exchange.

The main success of a bank is the success in carrying out its functions and role as a financial intermediary. Therefore, in addition to trying to maintain public trust, the bank must improve the quality of its performance (Tran \& Nguyen, 2020). Bank performance is the basis for measuring whether banks have carried out management activities in accordance with sound banking rules according to applicable regulations. The regulation of Bank Indonesia Number 13/24 / DPNP / 2011 states that the standard Return on Assets set for all banks in Indonesia is a minimum of 1.5\% (Bank Indonesia, 2011; Rachman et al., 2018; Yrigoy, 2018). The higher the ratio of Return on Assets in a bank, the higher the level of profit achieved by the bank; it also shows the dominant position 
of the bank in the use of assets (Miyazato, 2010; Rostami, Rostami, \& Kohansal, 2016). Bank performance can be measured from several financial ratios, among others, NonPerforming Loans that describe the quality of bank assets, in this case, the level of problem loans. Loan to Deposit Ratio, which is one of the achievements in measuring liquidity, and Capital Adequacy Ratio, which describes the ratio of adequacy of the bank's capital (Yrigoy, 2018; Baldwin, Alhalboni, \& Helmi, 2019; Choerudin \& Achmad, 2016).

The economic crisis that had occurred in Indonesia in 1997-1998 had a severe impact on the national banking industry, so that banks experienced liquidity problems. Assets worsened and were unable to generate earnings, which resulted in capital being absorbed very quickly (Sadli, 1998; Cole \& Slade, 1998). In contrast to current banking conditions, there have been many developments. The competition that occurs between commercial banks is increasingly tight. Banks compete with each other in terms of quality and improved performance to survive. Even so, the economic turmoil that moves dynamically created potential for opportunity, but also potential for losses. In the last few years, the banking industry has experienced severe conditions caused by the swelling of problem loans (Katadata.co.id, 2017). The growth rate of non-performing loans in several years is presented in Figure 1. In Asia, Indonesia is ranked as the country with the second highest level of non-performing loan risk after India (databoks. katadata.co.id, 2017).

The ratio of non-performing loans in banks in the fourth quarter of 2019 has seen an increase. Bank Indonesia (BI) noted that, as of October 2019, the Non-Performing Loan position had reached $2.73 \%$ on a gross basis. Also, the net NPL of the country rose to a level of $1.25 \%$. This position practically increased from the previous month, which recorded $2.66 \%$ gross and $1.18 \%$ net. Non-performing loan position in October 2019 is the highest level so far this year. Besides, when referring to the analysis summarized by CEIC Data, Indonesia's NPL is quite high when compared to neighboring countries in the September-October 2019 period. Five sectors caused the increase in NPLs: transportation, fisheries, trade, manufacturing, and construction sectors.

Based on national banking statistics as of July 2016, the surge in NPL ratios, among others, occurred in loans to the mining and quarrying industries. The increase in bad loans, which has initially $3.82 \%$ in July 2015 , rose to $6.76 \%$ in July 2016. The increase in the ratio of Non-Performing Loans must still be monitored by the Financial Services Authority (OJK) and the Deposit Insurance Corporation (LPS), especially if there are banks that are heading towards bankruptcy. Banks that have too high NPL ratios will certainly suffer losses, so they will have to increase capital to get back on their feet. The significant burden of NPL, aside from the mining sector, can also be found in micro, small, and medium credit (SME).

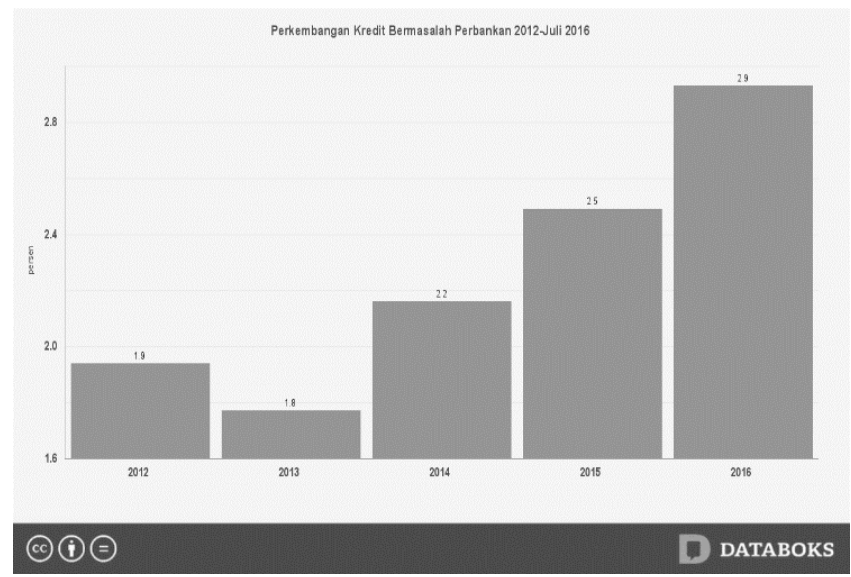

Source: www.Katadata.co.id (2017)

Figure 1: Non-Performing Banking Loans in Indonesia $2012-2016$

\section{Literature Review and Hypothesis Development}

The most significant risk of non-performing loans in banks is that it will also influence the value of the assets of the bank itself. Therefore, the profitability of a bank is the most critical measurement of the performance of a bank. Return on Assets focuses on the ability of a bank to benefit from its operations through its active capabilities. The higher the value of the non-performing loans or bad loans, the more it will affect the decline in profits/profits of a bank due to poor credit quality (Selling \& Stickney, 1989; Burton, Lauridsen, $\&$ Obel, 2002). Return on Assets is one of the basic measures to assess a company's profitability (Yanikkaya, Gumus, \& Pabuccu, 2018; Qayyum \& Noreen, 2019; Muhammad, Rehman, \& Waqas, 2016).

In the results of financial statement analysis, the ratio of Return on Assets is the most commonly highlighted element, because this ratio shows the success of a company in generating profits (Nguyen \& Nguyen, 2020). Return on Assets can measure the performance of a bank to generate profits, which can then be used to predict future profit levels for the survival of the company (Erasmus, 2010; Arquisola, Shella, \& Hutabarat, 2018). The ratio of net income divided by total assets measures the return on total assets after interest and tax expense (McGowan \& Stambaugh, 2012). Return on Assets measures the overall effectiveness in generating profits through assets. Return on Assets can also be interpreted as the ability to get benefits or advantages from invested capital.

A non-performing loan is a condition where customers can no longer afford repayments to banks according to the provisions of Bank Indonesia Regulation No.7 / 2 / PBI / 
2005. Non-performing loans to banks are situations where customers can no longer pay part or all of their obligations following the deed of an agreement made with the bank (Harianto, 2017; Messai \& Jouini, 2013; Louzis, Vouldis, \& Metaxas, 2012). Non-performing loans can generally be classified into several levels of collectability, namely, substandard, doubtful, and loss (Saba, Kouser, \& Azeem, 2012). Non-Performing Loans are an indication that there are problems in the bank, which, if not immediately followed up, will harm the bank. One of the adverse effects that will impact on the bank is that the owned capital will decrease. The problematic credit factor can be seen from various aspects, including the customer side (Kencana, Hariyani, \& Panjaitan, 2016), management factor (Haneef et al., 2012), operational factor (Adeyemi, 2011), as well as external sides such as economic conditions and the condition of the bank itself (Abid, Ouertani, \& Zouari-Ghorbel, 2014).

The stages of rescue and solutions for troubled credit include rescheduling, reconditioning, restructuring, and its combination (Shih, 2004). Banks with Non-Performing Loans that exceed the limit and increasingly lose money must increase their capital to be healthy again. The most significant risk of non-performing loans in banks is that they will also influence the value of the assets of the bank itself (Haneef et al., 2012; Cucinelli, 2015). Therefore, profitability is an essential measuring tool to see the good or bad performance of a bank. Factors for the occurrence of Non-Performing Loans include, firstly, the willingness or goodwill of the debtor, meaning that the debtor's ability from the financial side to pay off the principal and interest of the loan will be meaningless without the will and goodwill of the debtor itself. So, if many debtors have arrears in installments, this will trigger a higher level of Non-Performing Loans.

Secondly, the company will experience difficulties in paying its debts to the bank; likewise, the regulation of a country's parent bank has a direct or indirect effect on the Non-Performing Loans of a bank. For example, the State Bank of Indonesia raises the rate that will cause credit interest rates to go up. Naturally, the debtor's ability to repay the principal and interest on the loan will be reduced. Thirdly, economic conditions have a significant influence on the ability of debtors to pay off debts. Macroeconomic indicators that have an impact on Non-Performing Loans are influenced by inflation and exchange rates.

Banks or financial institutions indeed function to collect and distribute funds from and for the people (Siklos, 2008). To maximize credit conditions that are healthy and remain well coordinated, the bank must establish a management system on various aspects and parties involved because profitability is an essential indicator of bank performance. In general, the definition of Capital Adequacy Ratio is the ratio of capital adequacy to compensate for the risk of losses faced by banks (Allahrakha, Cetina, \& Munyan, 2018). Capital Adequacy
Ratio is a ratio that shows all bank assets that contain risks that are financed from their capital, in addition to getting funds from sources other than banks, such as funds from the public, loans, and others. Capital is an essential factor for banks to develop business and their strength to bear losses (Allahrakha et al., 2018; Akinci \& Olmstead-Rumsey, 2018). Therefore, based on the description in the sub-section of the literature review, the following hypotheses are formulated:

H1: Non-Performing Loans have a positive and significant effect on Return on Assets

H2: Capital Adequacy Ratio has a positive and significant effect on Return on Assets

\section{Research Methods and Materials}

\subsection{Samples}

This study uses secondary data, based on financial statements (Data Panel) for the period 2015-2019, which come from ten Conventional Banks listed on the IDX. Sample determination criteria include: 1) companies included in the banking companies listed on the Indonesia Stock Exchange during the study period 2015-2019;2) the bank is registered in the Indonesia Capital Market Directory (ICMD) during the study period; and 3) banking establishments publish their financial statements in a row during the research period and can be accessed by the public. Based on the above criteria, of the conventional bank population listed on the IDX in the 2020 observation period, fifty-one commercial banks listed on the IDX operating in Indonesia in 2015-2019 (See. Appendix 1) met the requirements as research samples; amounted to ten banks as in Table 1.

After checking primary data covering financial statements (2013-2017), some populations were declared unfit to be sampled due to hard-to-find/defective data and outlier data. So, the number of observational data to be processed in

Table 1: Research Samples of Ten Conventional Banks

\begin{tabular}{|l|l|}
\hline Code & Banks \\
\hline BCA & Bank Central Asia \\
\hline CIMB & Bank CIMB Niaga \\
\hline BDNM & Bank Danamon Indonesia \\
\hline BMDR & Bank Mandiri \\
\hline BII & Bank Maybank Indonesia \\
\hline MEGA & Bank Mega \\
\hline BNI & Bank Negara Indonesia \\
\hline BRI & BRI \\
\hline BBTN & Bank Tabungan Negara \\
\hline BTPN & Bank Tabungan Pensiunan Nasional \\
\hline
\end{tabular}

Source: IDX (2020) 
this study is the number of banks with several observation periods, namely, for five periods (2013 to 2017). So, the number of observations in this study for the bank group that went public totaled fifty observational data. Thus, the number of samples in this study met the minimum amount of observational data provisions $(\mathrm{n}=10)$. The list of bank's names that are sampled in this study can be seen as follows:

\subsection{Analysis Statistics}

The data analysis used the descriptive method to reveal and understand the truth obtained from observing secondary data sources, so it is expected to describe the financial data of banking companies in existing conditions. The analytical method used in this study is multiple linear regression with the equation of the regression formula is as follows:

$$
Y(R O A)=a+b a X a(N P L)+a b X b(C A R)+e
$$

The testing phase in this research is through various stages, namely: transformation of values to square (Compute variable) transformation, then after that, $\mathrm{F}$ test is as a simultaneous test ( $\mathrm{F}$ table $>\mathrm{F}$ Calculate) or statistical hypothesis test to find out whether the statistical hypothesis is accepted or rejected $(\mathrm{H} 0=$ Accepted or $\mathrm{H} 0=$ Rejected $)$. The $\mathrm{F}$ test value can be seen from the required significance value $(\mathrm{p}<0.05)$ (Field, Miles, \& Field, 2013; Meiyani \& Putra, 2019). T-test section is to test and determine the extent to which the independent variables affect the dependent variable. Test values can be seen from the required significance value of $p<0.05$. R2 test or coefficient of determination test is to determine the overall effect of independent variables on the dependent variable in the form of a percentage, the difference from the calculation of the value of R2 - $100 \%$ is the result of stating that other variables affect the dependent variable besides the studied variable (Field et al., 2013).

The normality test is a test to find out whether the data are normally distributed (parametric) or not normally distributed (non-parametric). The normality test is an absolute requirement in linear regression analysis and person correlation (Field et al., 2013; Razak, et al, 2020). Data are normally distributed through the Kolmogorov-Smirnov test with an Asymptotic Sig value $>0.05$ (Haerani et al, 2020). Multicollinearity test aims to determine whether or not there are irregularities in classical assumptions. The terms of multicollinearity are VIF values $<10$ and Tolerance Values $>$ 0.1 . A regression test is a test to determine the effect/causality between independent variables on the dependent variable. To find out, the regression coefficient can be seen through the coefficient value $\beta$ and $t$ value and the required significance value $\mathrm{p}<0.05$ (Field et al., 2013). The conceptual framework of the study was based on a theoretical review and the results of previous studies, as shown on Figure 2:

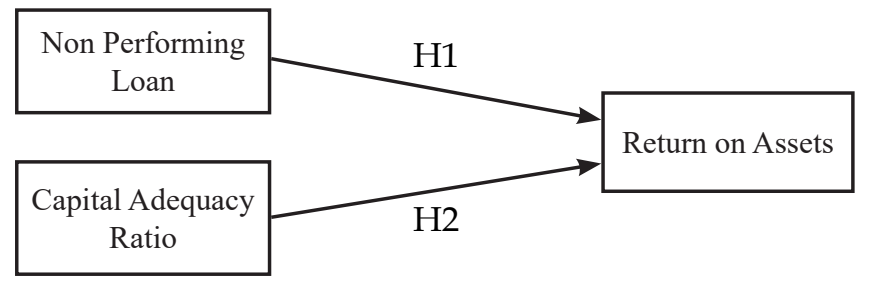

Figure 2: Conceptual Framework

\section{Results and Discussion}

\subsection{Statistical Results}

Appendix 2 shows the compilation of average data of Return on Assets, Non-Performing Loans, and Capital Adequacy Ratio in each study sample for the 2015-2019 period. The return ratio of bank company assets listed on the Indonesian stock exchange has fluctuated; for example, in 2013, BRI showed the highest Return on Assets value of $5.03 \%$ while in 2013 BBTN showed the lowest Return on Assets value of $1.63 \%$. In 2014, the highest Return on Assets was shown by BRI at $4.73 \%$, and BII showed the most moderate at $0.68 \%$. Then, BRI again showed the highest value in 2015, which was $4.19 \%$, and the lowest in 2015 was displayed by BII, which was $1.01 \%$.

In 2016, BRI returned the highest Return on Assets by $3.84 \%$, and BBTN showed the lowest at $1.59 \%$. In 2019, the highest and lowest Return On Assets of 3.80\% and $1.48 \%$ were shown by BCA and BII, where the ratio of Non-Performing Loans by BRI experienced an increase in the rate of problem loans starting from 2015-2019 (Appendix 2). The trend is that state-owned banks in the Non-Performing Loan ceiling are on the threshold of typical Non-Performing Loan ratios. In contrast, conventional private banks such as CIMB, BCA, BII, BTPN tend to make decisions to provide loans within the safe limit of $<3 \%$ ).

The difference in the pattern of decision-making also shows that the level of public confidence in banks in Indonesia related to credit loans is still more significant in the state-owned bank sector than private banks. The highest value of Capital Adequacy Ratio in 2015 was at BTPN bank, while the lowest Capital Adequacy Ratio was in BNI. In 2016, the highest Capital Adequacy Ratio value was with BTPN banks, while the most economical in 2016 was at CIMB banks. For 2017, the highest Capital Adequacy Ratio value is owned by BTPN while BII owns the lowest. In 2018, the highest Capital Adequacy Ratio was owned by MEGA banks, while CIMB banks own the lowest Capital Adequacy Ratio. Finally, for 2019, the highest Capital Adequacy Ratio value is owned by BTPN banks, while BNI holds the lowest Capital Adequacy Ratio value. 
Table 2: Recapitulation of Return on Assets, Non-Performing Loans, and Capital Adequacy Ratio Samples

\begin{tabular}{|l|l|l|l|}
\hline Year & NPL & CAR & ROA \\
\hline 2015 & 1.60 & 17.18 & 3.01 \\
\hline 2016 & 1.85 & 17.96 & 2.36 \\
\hline 2017 & 2.41 & 19.65 & 2.31 \\
\hline 2018 & 2.78 & 21.58 & 2.46 \\
\hline 2019 & 2.47 & 20.89 & 2.61 \\
\hline Highest average & 2.78 & 21.58 & 3.01 \\
\hline Lowest average & 1.60 & 17.18 & 2.31 \\
\hline
\end{tabular}

Table 3: Statistics Results

\begin{tabular}{|c|c|c|c|c|}
\hline \multicolumn{5}{|c|}{ F-test $=7.063, \operatorname{Sig}(0.011<0.05)$} \\
\hline t-test & \multicolumn{2}{|c|}{ partial } & \multicolumn{2}{|c|}{ sig } \\
\hline CAR & \multicolumn{2}{|c|}{-0.045} & \multicolumn{2}{|c|}{$0.760>0.05$} \\
\hline NPL & \multicolumn{2}{|c|}{-0.359} & \multicolumn{2}{|c|}{$0.011<0.05$} \\
\hline \multicolumn{5}{|c|}{$R^{2}=0.128$} \\
\hline \multicolumn{5}{|c|}{ Normality test $=0.200>0.05($ Normal $)$} \\
\hline Multicollinearity-test & \multicolumn{2}{|c|}{ Tolerance } & \multicolumn{2}{|c|}{ VIF } \\
\hline CAR & \multicolumn{2}{|c|}{0.954} & \multicolumn{2}{|c|}{1.048} \\
\hline NPL & \multicolumn{2}{|c|}{0.954} & \multicolumn{2}{|c|}{1.048} \\
\hline Regression-Test & B & $\begin{array}{l}\text { Std. } \\
\text { error }\end{array}$ & $\mathrm{t}$ & Sig \\
\hline CAR & -0.014 & 0.044 & -0.308 & 0.760 \\
\hline NPL & -0.370 & 0.140 & -2.637 & 0.011 \\
\hline
\end{tabular}

Table 2 shows that the Non-Performing Loans, Capital Adequacy Ratio, and Return On Assets of banking companies listed on the Indonesia Stock Exchange during the study period, 2015-2019, fluctuated. In 2019, banking companies showed the highest average Non-Performing Loans, with the highest average in 2018 (2.78\%) and the lowest in 2015 (1.60\%). The highest average Return on Assets was 3.01 in the 2015 period, while the lowest average occurred in the 2017 period, $2.31 \%$.

Table 3 states the data feasibility test, such as the validity test. All measurement items were declared valid with high correlation criteria (Cronbach's alpha $>0.8$ ) with a significance level $(\mathrm{p}<0.01)$. The reliability test also showed a high value of $>0.9$. Simultaneously, the Non-Performing Loans and Capital Adequacy Ratio have a significant influence. The coefficient of determination (R2) test states a value of 0.128 or $12.8 \%$. So, it can be noted that the Capital Adequacy Ratio and Non-Performing Loans affect the Return on Assets of $12.8 \%$, and $88.2 \%$ of the Return on Assets of banks in Indonesia are influenced by other variables besides the Capital Adequacy Ratio and Non-Performing Loans. The normality test using the Kolmogorov-Smirnov test (Figure 3) shows that the test variable is declared normal ( $\operatorname{sig} 0.200>0.05$ ), and there is no multicollinearity on the test items because the VIF value of the Non-Performing Loan variable and the Capital Adequacy Ratio is $<10$.

Figure 3 explains that the normality curve forms a symmetrical, bell-shaped, centered line. On the right, it shows that the plot is spread close to the diagonal line. So, it was concluded that the data of this study were usually distributed.

Furthermore, in the regression test, the test results show that the Non-Performing Loan variable has significant and negative influence or effect, but not directly on Return On Assets ( $\operatorname{sig} 0.011<0.05, \mathrm{t}=-2.637$ ) While the Capital Adequacy Ratio does not have a significant impact on Return On Assets (sig. $0.760>0.05$, the regression equation is:

$$
\begin{aligned}
Y(R O A) & =3.634+(-0.14) C A R+(-0.370) N P L \\
& =0.044(\text { error })
\end{aligned}
$$

Regression calculation results can be assumed that there is a constant state of Non-Performing Loans with an indirect effect contributing to Return on Assets of 3.5\%, while in a continuous state of Return on Assets of 3,634. If the Capital Adequacy Ratio variable is entered, it will reduce the Return on Assets value due to an insignificant Capital Adequacy Ratio, which has initially been from 3,634 to 3,568 or reduced by 0.066 points. Based on the results of regression testing, the research hypothesis test is as follows:

H1: Non-Performing Loans affect conventional Bank Return on Assets recorded on IDX. From the results of the data analysis, the value of statistical testing states that the Non-Performing Loan variable has a significant negative effect on Return on Assets with a sig value. $0.011<0.05$. So, it can be stated that $\mathrm{H} 1$ = accepted
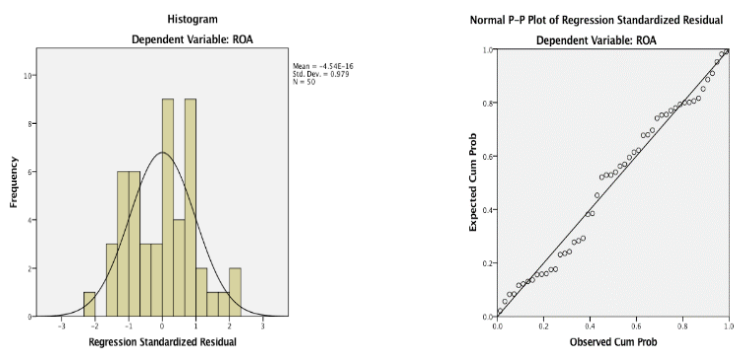

Figure 3: Scatterplots \& Curves of Normality and Heterokedastisity 
H2: Capital Adequacy Ratio affects the conventional Bank Return on Assets recorded on IDX. From the results of data analysis, the value of statistical testing states that the variable. Capital Adequacy Ratio has no effect on Return on Assets with sig. $0.760>0.05$. So, it can be stated that $\mathrm{H} 2=$ rejected.

\subsection{Discussion}

Non-Performing Loans is one of the key indicators to assess the performance of bank functions. One of the features of a bank is as an intermediary institution or a liaison between parties who have excess funds and those who need funds. The results of research on Non-Performing Loans on Return on Assets in ten conventional banks listed on the Indonesia Stock Exchange stated that the t-value was $-2,637$, while the t-table had the significant number of $0.011<0.05$. Based on decision-making criteria, it can be concluded that Non-Performing Loans have a significant, but indirect effect on Return on Assets on ten well-known banking companies listed on the IDX. This indicates that the higher the NonPerforming Loans in bank loan management, the lower the level of bank income reflected through Return on Assets, but the impact is not necessarily direct.

Capital is a major factor for a bank to be able to grow its business. Capital Adequacy Ratio serves to accommodate the risk of loss that may be faced by banks. The higher the Capital Adequacy Ratio, the better the bank's ability to bear the risk of any risky credit/earning assets. If the value of the Capital Adequacy Ratio is high then the bank is able to finance operational activities and make a sizeable contribution to profitability. In accordance with capital theory, capital is an important factor for banks in the context of developing a business and accommodating losses. The capital adequacy ratio means the amount of own capital needed to cover the risk of losses that may arise from investing assets that contain risks. It is based on the results of research on the Capital Adequacy Ratio of Return On Assets in ten conventional banks listed on the Indonesia Stock Exchange, which stated that the count is -0.308 while t-table has the significant number of $0.760>0.05$. The insignificance of Capital Adequacy Ratio to Return on Assets is likely due to Bank Indonesia regulations that require each bank to maintain Capital Adequacy Ratio with a minimum requirement of $8 \%$, so that bank owners increase bank capital by providing funds (fresh money) to anticipate business scale expansion in the form of credit or loans that the capital adequacy ratio of the bank can comply with Bank Indonesia.

The results of this study assume that as banks are less able to extend credit, banks, and capital owners are more dominant in buying Bank Indonesia Certificates (SBI) where the Risk-Weighted Assets (ATMR) of Indonesian bank interest rates by banks is null. Thus, the Risk-Weighted
Assets (ATMR) banks are relatively small, so that the Capital Adequacy Ratio remains significant, and this could be due to the banking crisis. So, it is natural that the Capital Adequacy Ratio is not substantial to Return on Assets because, even though the capital owned by banks is high, public trust is still low, and this will not have an impact on bank profitability. Or also because banks tend to invest their funds carefully and put more emphasis on bank survival so that the Capital Adequacy Ratio does not have much effect on bank profitability.

\section{Conclusions}

Non-Performing Loans have a significant negative impact on conventional banks listed on the IDX, or it can be said that Non-Performing Loans indirectly affect the Return on Assets. Capital Adequacy Ratio does not affect the Return on Assets of conventional banks listed on the IDX. NonPerforming Loans and Capital Adequacy Ratio have an effect of 0.128 or $12.8 \%$ on the level of Return on Assets. So, there are still around $87.2 \%$, which affects the rise and fall of the ratio of Return on Assets other than Non-Performing Loans and Capital Adequacy Ratio. Because Return on Assets and Capital Adequacy Ratio variables have a significant effect on NPL variables, it is necessary for the banks, governments, and authorities monetary and related institutions to deploy efforts to maintain the stability of these variables. This is because, if a balance is created either in the form of values or amounts of these variables, the reduction in Non-Performing Loans will be controlled as expected.

\section{References}

Abid, L., Ouertani, M. N., \& Zouari-Ghorbel, S. (2014). Macroeconomic and bank-specific determinants of household's non-performing loans in Tunisia: A dynamic panel data. Procedia Economics and Finance, 13, 58-68. https://doi.org/10.1016/S2212-5671(14)00430-4

Adeyemi, B. (2011). Bank failure in Nigeria: A consequence of capital inadequacy, lack of transparency and non-performing loans. Banks and Bank Systems, 6(1), 99-109.

Akinci, O., \& Olmstead-Rumsey, J. (2018). How effective are macroprudential policies? An empirical investigation. Journal of Financial Intermediation, 33, 33-57. https://doi.org/10.1016/j.jfi.2017.04.001

Allahrakha, M., Cetina, J., \& Munyan, B. (2018). Do higher capital standards always reduce bank risk? The impact of the Basel leverage ratio on the US triparty repo market. Journal of Financial Intermediation, 34(April). https://doi.org/10.1016/j.jfi.2018.01.008

Arquisola, M. J., Shella, K., \& Hutabarat, E. (2018). How does board diversity affect the financial performance of commercial 
banks in indonesia? An inquiry. Jurnal Manajemen, 22(1), 6273. http://dx.doi.org/10.24912/jm.v22i1.313

Baldwin, K., Alhalboni, M., \& Helmi, M. H. (2019). A structural model of "alpha" for the capital adequacy ratios of Islamic banks. Journal of International Financial Markets, Institutions and Money, 60(May), 267-283. https://doi.org/10.1016/j. intfin.2018.12.015

Bank Indonesia. (2011). BI Circular Regarding Rating of Soundness of Commercial Banks. pp. 1-28. Bank Indonesia. Retrieved March 20, 2020, from https:/www.bi.go.id/id/peraturan/ perbankan/pages/ketentuan\%20perbankan.aspx

Burton, R. M., Lauridsen, J., \& Obel, B. (2002). Return on assets loss from situational and contingency misfits. Management Science, 48(11), 1461-1485. https://doi.org/10.1287/ mnsc.48.11.1461.262

Choerudin, C., \& Achmad., E. (2016). The Effect of Non Perfoming Loan (NPL) and Loan To Deposit Ratio (LDR) on Return On Assets (ROA) with Capital Adequacy Ratio (CAR) as Intervening Variables (Studies on Commercial Banks Registered on IDX for the Period 2012-2015), ProBank, Jurnal Ekonomi dan Perbankan, 2(2), 28-47.

Cole, D. C., \& Slade, B. F. (1998). Why has Indonesia's financial crisis been so bad? Bulletin of Indonesian Economic Studies, 34(2), 61-66. https://doi.org/10.1080/00074919812331337330

Cucinelli, D. (2015). The impact of non-performing loans on bank lending behavior: evidence from the Italian banking sector. Eurasian Journal of Business and Economics, 8(16), 59-71. https://doi.org/10.17015/ejbe.2015.016.04

Databoks.katadata.co.id. (2017). In ASEAN, Indonesian Banking NPL is quite high in Databoks. Retrieved March 11, 2020, from https://databoks.katadata.co.id/datapublish/2017/05/15/2016npl-perbankan-indonesia-cukup-tinggi

Erasmus, P. D. (2010). Working capital management and profitability: The relationship between the net trade cycle and return on assets. Management Dynamics: Journal of the Southern African Institute for Management Scientists, 19(1), 2-10.

Field, A., Miles, J., \& Field, Z. (2013). Discovering Statistics Using SPSS (Vol. 81). ISBN: 1446249182, London, Sage, 1-816. https://doi.org/10.1111/insr.12011_21

Haerani, S., Sumardi, S., Hakim, W., Hartini, H., \& Putra, A. H. P. K. (2020). Structural Model of Developing Human Resources Performance: Empirical Study of Indonesia States Owned Enterprises. Journal of Asian Finance, Economics and Business, 7(3), 211-221. https://doi.org/10.13106/jafeb.2020. vol7.no3.211

Haneef, S., Riaz, T., Ramzan, M., Rana, M. A., Hafiz, M. I., \& Karim, Y. (2012). Impact of risk management on non-performing loans and profitability of banking sector of Pakistan. International Journal of Business and Social Science, 3(7), 307-315.

Harianto, S. (2017). Financial Ratios and The Effects on Profitability at Islamic People's Financing Banks. Esensi: Jurnal Bisnis Dan Manajemen, 7(1), 41-48. https://doi.org/10.15408/ess. v7i1.4076
Katadata.co.id. (2017). Bank Conditions Improve, OJK Tightens Loan Restructuring Rules - Katadata News. Retrieved January 18, 2018, from https://katadata.co.id/berita/2017/08/22/kinerjabank-membaik-ojk-perketat-lagi-aturan-restrukturisasi-kredit

Kencana, S. S., Hariyani, H., \& Panjaitan, F. (2016). Analysis of the Effect of Debtor Characteristics Based on Principle 5c on Non-Performing Loans (Case Study in Mega Central Finance, Bangka Branch). Jurnal Progresif Manajemen Bisnis, 14(2), 46-58. http://dx.doi.org/10.15408/ess.v7i1.4076

Louzis, D. P., Vouldis, A. T., \& Metaxas, V. L. (2012). Macroeconomic and bank-specific determinants of nonperforming loans in Greece: A comparative study of mortgage, business and consumer loan portfolios. Journal of Banking \& Finance, 36(4), 1012-1027. https://doi.org/10.1016/j. jbankfin.2011.10.012

McGowan, C. B., \& Stambaugh, A. R. (2012). Using disaggregated return on assets to conduct a financial analysis of a commercial bank using an extension of the DuPont system of financial analysis. Accounting and Finance Research, 1(1), 152-161. http://dx.doi.org/10.5430/afr.v1n1p152

Meiyani, E., \& Putra, A. H. P. K. (2019). The relationship between islamic leadership on employee engagement distribution in FMCG industry: Anthropology business review. Journal of Distribution Science, 17(5), 19-28. http://dx.doi.org/10.15722/ jds.17.05.201905.19

Messai, A. S., \& Jouini, F. (2013). Micro and macro determinants of non-performing loans. International Journal of Economics and Financial Issues, 3(4), 852-860.

Miyazato, N. (2010). The optimal size of Japan's public pensions: An analysis considering the risks of longevity and volatility of return on assets. Japan and the World Economy, 22(1), 31-39. https://doi.org/10.1016/j.japwor.2009.06.001

Muhammad, H., Rehman, A. U., \& Waqas, M. (2016). The Relationship between Working Capital Management and Profitability: A Case Study of Tobacco Industry of Pakistan. Journal of Asian Finance, Economics and Business, 3(2), 1320. https://doi.org/10.13106/jafeb.2016.vol3.no2.13.

Nguyen, T. N. L., \& Nguyen, V. C. (2020). The Determinants of Profitability in Listed Enterprises: A Study from Vietnamese Stock Exchange. Journal of Asian Finance, Economics and Business, 7(1), 47-58. https://doi.org/10.13106/jafeb.2020.vol7.no1.47

Qayyum, N. U., \& Noreen, U. (2019). Impact of Capital Structure on Profitability: A Comparative Study of Islamic and Conventional Banks of Pakistan. Journal of Asian Finance, Economics and Business, 6(4), 65-74. https://doi.org/10.13106/jafeb.2019.vol6.no4.65

Rachman, R. A., Kadarusman, Y. B., Anggriono, K., \& Setiadi, R. (2018). Bank-specific Factors Affecting Non-performing Loans in Developing Countries: Case Study of Indonesia. Journal of Asian Finance, Economics and Business, 5(2), 35-42. https://doi.org/10.13106/jafeb.2018.vol5.no2.35

Razak, M., Hidayat, M., Launtu, A., Kusuma Putra, A. and Bahasoan, S. (2020). Antecedents and consequence of brand 
management: empirical study of Apple's brand product. Journal of Asia Business Studies [Online First]. https://doi.org/10.1108/ JABS-01-2019-0030

Rostami, S., Rostami, Z., \& Kohansal, S. (2016). The Effect of Corporate Governance Components on Return on Assets and Stock Return of Companies Listed in Tehran Stock Exchange. Procedia Economics and Finance, 36(2), 137-146. https://doi.org/10.1016/S2212-5671(16)30025-9

Saba, I., Kouser, R., \& Azeem, M. (2012). Determinants of Non Performing Loans: Case of US Banking Sector. The Romanian Economic Journal, 44(6), 125-136.

Sadli, M. (1998). The Indonesian Crisis. Economics and Finance in Indonesia, 56(1), 97-110.

Selling, T. I., \& Stickney, C. P. (1989). The effects of business environment and strategy on a firm's rate of return on assets. Financial Analysts Journal, 45(1), 43-52. https://doi. org/10.2469/faj.v45.n1.43

Shih, V. (2004). Dealing with non-performing loans: Political constraints and financial policies in China.
The China Quarterly, 180(December), 922-944. https://doi.org/10.1017/S0305741004000682

Siklos, P. L. (2008). No single definition of central bank independence is right for all countries. European Journal of Political Economy, 24(4), 802-816. https://doi.org/10.1016/j.ejpoleco.2008.07.004

Tran, S. H., \& Nguyen, L. T. (2020). Financial Development, Business Cycle and Bank Risk in Southeast Asian Countries. Journal of Asian Finance, Economics and Business, 7(3), 127135. https://doi.org/10.13106/jafeb.2020.vol7.no3.127

Yanikkaya, H., Gumus, N., \& Pabuccu, Y. U. (2018). How profitability differs between conventional and Islamic banks: A dynamic panel data approach. Pacific-Basin Finance Journal, 48(April), 99-111.https://doi.org/10.1016/j.pacfin.2018.01.006

Yrigoy, I. (2018). Transforming non-performing loans into re-performing loans: Hotel assets as a post-crisis rentier frontier in Spain. Geoforum, 97(December), 169-176. https://doi.org/10.1016/j.geoforum.2018.11.001 
Appendix 1: Research Population of Ten Conventional Banks

\begin{tabular}{|c|c|c|c|}
\hline No & Code & Bank & Info \\
\hline 1 & B-ANZP & ANZ Indonesia & Not Sample \\
\hline 2 & B-AG & Artha Graha International & Not Sample \\
\hline 3 & B-BKPN & Bukopin & Not Sample \\
\hline 4 & C-BKPN & Bukopin Kustodian & AR not found \\
\hline 5 & B-BCA & Bank Central Asia & Not Sample \\
\hline 6 & C-BCA & Central Asia Kustodian & Sample \\
\hline 7 & B-CAPT & Capital Indonesia & Not Sample \\
\hline 8 & B-BNGA & CIMB Niaga & Not Sample \\
\hline 9 & C-BNGA & CIMB Niaga Kustodian & Sample \\
\hline 10 & B-COMM & Common Wealth & Not Sample \\
\hline 11 & B-CHNA & CTBC Indonesia & Not Sample \\
\hline 12 & B-BDNM & Danamon Indonesia & AR not found \\
\hline 14 & B-DBSB & DBS Indonesia & Sample \\
\hline 15 & C-DBSB & DBS Indonesia Kustodian & AR not found \\
\hline 16 & B-HSBC & HSBC Indonesia & AR not found \\
\hline 17 & C-HSBC & HSBC Indonesia Kustodian & AR not found \\
\hline 18 & B-INPB & Ina Perdana & Data unknown \\
\hline 19 & B-MUTI & J-Trust Indonesia & AR not found \\
\hline 20 & B-HNBN & KEB Hana Indonesia & AR not found \\
\hline 21 & B-BMDR & Mandiri & AR not found \\
\hline 22 & C-BMDR & Mandiri Kustodian & Sample \\
\hline 23 & B-BII & Maybank Indonesia & Not Sample \\
\hline 24 & C-BII & Maybank Indonesia Kustodian & Sample \\
\hline 25 & B-MEGA & Mega & Not Sample \\
\hline 26 & C-MEGA & Mega Kustodian & Sample \\
\hline 27 & B-BMPT & MNC Internasional & Not Sample \\
\hline 28 & $\mathrm{~B}-\mathrm{BNI}$ & Bank Negara Indonesia & AR not found \\
\hline 29 & C-BNI & Bank Negara Indonesia Kustodian & Sample \\
\hline 30 & B-NISP & OCBC NISP & Not Sample \\
\hline 31 & B-BOFA & Bank of America & Data Outlier \\
\hline 32 & B-BTMU & Bank of Tokyo Mistshubishi & Not Sample \\
\hline 33 & B-PNBN & Bank Pan Indonesia & Not Sample \\
\hline 34 & C-PNBN & Bank Pan Indonesia Kustodian & AR not found \\
\hline 35 & C-BBJB & Bank Pembangunan Daerah Jawa Barat dan Banten Kustodian & Not Sample \\
\hline 36 & B-BALI & Permata & Not Sample \\
\hline 37 & C-BALI & Permata Kustodian & Data unknown \\
\hline 38 & B-AWAN & QNB Indonesia & Not Sample \\
\hline 39 & B-RABO & Rabobank Indonesia & Data unknown \\
\hline 40 & B-BRI & BRI & Data unknown \\
\hline 41 & C-BBRI & BRI Kustodian & Sample \\
\hline 42 & B-AGRO & BRI Agroniaga & Not Sample \\
\hline 43 & B-BBTN & Bank Tabungan Negara Indonesia & Not Sample \\
\hline 44 & B-BTPN & Bank Tabungan Pensiunan Nasional & Sample \\
\hline 45 & C-UOBB & UOB Indonesia Kustodian & Sample \\
\hline 46 & B-BBIA & UOB Indonesia & \\
\hline 47 & $\mathrm{~B}-\mathrm{VICT}$ & Bank Victoria Internasional & Not Sample \\
\hline 48 & B-CBNA & Citibank N.A & Not Sample \\
\hline 49 & C-CBNA & Citibank N.A Kustodian & AR not found \\
\hline 50 & B-DBAG & Deutsche Bank AG Jakarta Branch & Not Sample \\
\hline 51 & C-DBAG & Deutsche Bank AG Jakarta Branch Kustodian & Sample \\
\hline
\end{tabular}

Source: IDX, 2020 
Appendix 2: ROA, NPL and CAR

\begin{tabular}{|c|c|c|c|c|c|c|}
\hline \multirow{2}{*}{ No. } & \multirow{2}{*}{ Bank } & \multicolumn{5}{|c|}{ ROA (\%) } \\
\hline & & 2015 & 2016 & 2017 & 2018 & 2019 \\
\hline 1. & BCA & 3.34 & 3.42 & 3.40 & 3.50 & 3.80 \\
\hline 2. & CIMB. & 2.49 & 1.10 & 2.10 & 2.75 & 2.85 \\
\hline 3. & BDNM & 3.4 & 1.8 & 1.7 & 2.3 & 3.0 \\
\hline 4. & BMDR & 3.66 & 3.57 & 3.15 & 1.95 & 2.72 \\
\hline 5. & BII & 1.74 & 0.68 & 1.01 & 1.60 & 1.48 \\
\hline 6. & MEGA & 2.33 & 1.98 & 1.77 & 2.45 & 2.29 \\
\hline 7. & BNI & 3.36 & 3.49 & 2.6 & 2.7 & 2.7 \\
\hline 8. & BRI & 5.03 & 4.73 & 4.19 & 3.84 & 3.69 \\
\hline 9. & BBTN & 1.63 & 1.07 & 1.47 & 1.59 & 1.56 \\
\hline 10. & BTPN & 3.14 & 1.75 & 1.75 & 1.87 & 2.02 \\
\hline \multirow{2}{*}{ No } & \multirow{2}{*}{ Bank } & \multicolumn{5}{|c|}{ NPL (\%) } \\
\hline & & 2015 & 2016 & 2017 & 2018 & 2019 \\
\hline 1. & BCA & 0.4 & 0.6 & 0.7 & 1.3 & 1.5 \\
\hline 2. & CIMB & 2.23 & 3.90 & 3.74 & 3.89 & 3.75 \\
\hline 3. & BDNM & 1.3 & 1.5 & 3.0 & 3.1 & 2.8 \\
\hline 4. & BMDR & 1.60 & 1.66 & 2.29 & 3.96 & 3.45 \\
\hline 5. & BII & 2.11 & 2.23 & 3.67 & 3.42 & 2.81 \\
\hline 6. & MEGA & 2.18 & 2.09 & 2.81 & 3.44 & 2.01 \\
\hline 7. & $\mathrm{BNI}$ & 2.17 & 1.96 & 2.7 & 3.0 & 2.3 \\
\hline 8. & BRI & 1.55 & 1.69 & 2.02 & 2.03 & 2.10 \\
\hline 9. & BBTN & 1.77 & 2.16 & 2.49 & 2.90 & 3.07 \\
\hline 10. & BTPN & 0.7 & 0.7 & 0.7 & 0.8 & 0.9 \\
\hline \multicolumn{2}{|r|}{ Highest NPL } & 2.23 & 3.90 & 3.74 & 3.96 & 3.75 \\
\hline \multicolumn{2}{|r|}{ Lowest NPL } & 0.4 & 0.60 & 0.7 & 0.8 & 0.9 \\
\hline \multicolumn{2}{|r|}{ NPL average } & 1.60 & 1.85 & 2.41 & 2.78 & 2.47 \\
\hline \multirow{2}{*}{ No } & \multirow{2}{*}{ Bank } & \multicolumn{5}{|c|}{ CAR (\%) } \\
\hline & & 2015 & 2016 & 2017 & 2018 & 2019 \\
\hline 1. & BCA & 21.8 & 21.2 & 18.6 & 22.4 & 19.8 \\
\hline 2. & CIMB & 15.36 & 15.58 & 16.28 & 17.96 & 18.60 \\
\hline 3. & BDNM & 17.9 & 17.9 & 19.7 & 20.9 & 22.1 \\
\hline 4. & BMDR & 14.93 & 16.60 & 18.60 & 21.36 & 21.64 \\
\hline 5. & BII & 12.74 & 15.76 & 15.17 & 16.77 & 17.53 \\
\hline 6. & MEGA & 15.74 & 15.23 & 22.85 & 26.21 & 24.11 \\
\hline 7. & $\mathrm{BNI}$ & 15.09 & 16.22 & 19.5 & 19.4 & 18.5 \\
\hline 8. & BRI & 16.99 & 18.31 & 20.59 & 22.91 & 22.96 \\
\hline 9. & BBTN & 18.13 & 19.57 & 21.39 & 22.93 & 19.04 \\
\hline 10. & BTPN & 23.1 & 23.2 & 23.8 & 25.0 & 24.6 \\
\hline
\end{tabular}

